\title{
Oxygen Availability from the Blood and the Effect of Phosphate Replacement on Erythrocyte 2,3-Diphosphoglycerate and Haemoglobin-Oxygen Affinity in Diabetic Ketoacidosis
}

\author{
O. M. Gibby ${ }^{1}$, K. E. A. Veale, T. M. Hayes, J. G. Jones, C. A. J. Wardrop \\ The Departments of Medicine and Haematology, Welsh National School of Medicine, University Hospital of Wales, Heath Park, Cardiff, \\ and The Biochemistry Department, University College, Cardiff, Wales
}

\begin{abstract}
Summary. Eleven patients with diabetic ketoacidosis were given intravenous phosphate in doses (mean $118 \mathrm{mmol}$; range $83-320 \mathrm{mmol}$ ) adequate to maintain normal plasma phosphate, in addition to a standard treatment regime. Prevention of hypophosphataemia stimulated recovery of the initially low red-cell 2,3-diphosphoglycerate concentrations (10.6 $\pm 5.8(\mathrm{SD}) \mu \mathrm{mol} / \mathrm{g} \mathrm{Hb})$ after twenty-four hours. In ten control patients (initial concentration $8.1 \pm 4.4$ $\mu \mathrm{mol} / \mathrm{g} \mathrm{Hb}$ ) treated without phosphate replacement, significantly lower red-cell 2,3-diphosphoglycerate concentrations were found between 2 and 6 days after admission (forty-eight hour value for control patients $14.6 \pm 1.6$ and for phosphate-treated patients $18.9 \pm 4.1 \mu \mathrm{mol} / \mathrm{g} \mathrm{Hb} ; \mathrm{p}<0.01$ ). However, no effect on in vivo p 50 or on the availability of oxygen from the blood resulted from the higher 2,3diphosphoglycerate levels. Maintenance of normal plasma phosphate levels by intravenous phosphate is, therefore, not indicated to improve tissue oxygenation in diabetic ketoacidosis.
\end{abstract}

Key words: Diabetic ketoacidosis, phosphate, erythrocyte, 2,3-diphosphoglycerate, haemoglobin-oxygen affinity, oxygen availability.

Diabetic ketoacidosis remains a dangerous condition with a reported mortality of $6-10 \%$ in units having a special interest in its treatment [1]. It has long been known that low concentrations of red-cell 2,3diphosphoglycerate (2,3-DPG) occur in this condition $[2,3,4]$. These low concentrations of 2,3-DPG

\footnotetext{
1 Present address: Dr. O. M. Gibby, Department of Clinical Biochemistry, New Addenbrookes Hospital, Cambridge
}

tend to lessen the ability of the blood to release oxygen and so may cause tissue hypoxia. In diabetic ketoacidosis red cell 2,3-DPG concentrations may take up to five days to return to normal [4]. Hypophosphataemia also develops during the treatment of diabetic keoacidosis, and there is a close correlation between the rate of return to normal of plasma phosphate and of red-cell 2,3-DPG [7]. Consequently, many workers have suggested that phosphate administration should be part of the management of diabetic ketoacidosis, $[4,7,8,9]$. The aim of this would be to hasten the recovery of red-cell 2,3DPG and thus to improve oxygen availability from the blood. However, no information has been available as to the efficacy of phosphate in enhancing oxygen release in diabetic ketoacidosis. We have measured plasma phosphate, red-cell 2,3-DPG and the haemoglobin-oxygen affinity during the ten days following admission to hospital in 21 patients, 11 of whom received phosphate replacement in addition to a standard regime for diabetic ketoacidosis.

\section{Patients, Materials and Methods}

Consecutive patients were included in the study if they were in diabetic ketoacidosis, with an arterial blood $\mathrm{pH}$ of less than 7.35, a blood glucose concentration greater than $25 \mathrm{mmol} / 1$ and ketonuria. Three patients, one of whom was studied on three occasions, are represented in both groups. Three other patients were retrospectively omitted from this report, two patients who died (a 79-year old woman with cardiac failure and mitral valve disease, and a 52-year old man after a massive myocardial infarct), and a third patient with acute renal failure. In all 3 patients it was felt that the complications would themselves interfere with oxygen handling and complicate the interpretation of the results.

All patients received a constant insulin (Actrapid M. C., Novo) infusion, starting at 6.6 iu/hour (not corrected for insulin adsorption to plastic syringe and tubing) via a Harvard pump. The infusion rate was gradually reduced to maintain a blood glucose of less than $10 \mathrm{mmol} / 1$. Fluid and electrolyte replacement were given as 
Table 1. Control patients (Group 1)

\begin{tabular}{|c|c|c|c|c|c|c|c|c|}
\hline $\begin{array}{l}\text { Patient } \\
\text { number }\end{array}$ & Sex & $\begin{array}{l}\text { Age } \\
\text { (years) }\end{array}$ & $\begin{array}{l}\text { Duration } \\
\text { diabetes } \\
\text { (years) }\end{array}$ & $\begin{array}{l}\text { Blood glucose } \\
(\mathrm{mmol} / \mathrm{l})\end{array}$ & $\mathrm{pH}$ & $\begin{array}{l}\text { Daily insulin } \\
\text { (Units) }\end{array}$ & $\begin{array}{l}\text { Duration } \\
\text { of insulin } \\
\text { infusion } \\
\text { (h) }\end{array}$ & $\begin{array}{l}\text { Other } \\
\text { medical } \\
\text { conditions }\end{array}$ \\
\hline 1 & $\mathrm{~F}$ & 45 & 14 & 36.0 & 7.11 & 48 & 36 & Gall bladder disease \\
\hline 2 & $\mathrm{~F}$ & 45 & 14 & 37.2 & 6.98 & 36 & 44 & Gall bladder disease \\
\hline 3 & $\mathbf{M}$ & 54 & 19 & 33.0 & 7.24 & 52 & 27 & \\
\hline 4 & $F$ & 69 & 35 & 43.2 & 6.85 & 20 & 57 & Pulmonary fibrosis \\
\hline 5 & $\mathbf{M}$ & 20 & 10 & 35.0 & 7.25 & 58 & 19 & \\
\hline 6 & $\mathbf{M}$ & 64 & 33 & 44.8 & 7.04 & 28 & 51 & \\
\hline 7 & $\mathrm{M}$ & 71 & 9 & 49.0 & 6.95 & 68 & 45 & \\
\hline 8 & $\mathrm{M}$ & 50 & 20 & 59.0 & 6.98 & 22 & 66 & \\
\hline 9 & $\mathbf{M}$ & 14 & New & 34.8 & 7.30 & - & 6 & \\
\hline 10 & $\mathrm{~F}$ & 72 & New & 47.6 & 7.18 & - & 52 & Perineal abscess \\
\hline Mean & & 50 & 15 & 42.0 & 7.09 & 33 & 40 & \\
\hline
\end{tabular}

Table 2. Phosphate treated patients (Group 2)

\begin{tabular}{|c|c|c|c|c|c|c|c|c|}
\hline $\begin{array}{l}\text { Patient } \\
\text { number }\end{array}$ & Sex & $\begin{array}{l}\text { Age } \\
\text { (years) }\end{array}$ & $\begin{array}{l}\text { Duration } \\
\text { diabetes } \\
\text { (years) }\end{array}$ & $\begin{array}{l}\text { Blood glucose } \\
(\mathrm{mmol} / 1)\end{array}$ & $\mathrm{pH}$ & $\begin{array}{l}\text { Daily insulin } \\
\text { (Units) }\end{array}$ & $\begin{array}{l}\text { Duration } \\
\text { of insulin } \\
\text { infusion } \\
\text { (h) }\end{array}$ & $\begin{array}{l}\text { Other } \\
\text { medical } \\
\text { conditions }\end{array}$ \\
\hline 11 & $\mathrm{~F}$ & 45 & 14 & 48.0 & 6.97 & 52 & 72 & Gall bladder disease \\
\hline 12 & $\mathrm{M}$ & 20 & 10 & 34.5 & 7.27 & 54 & 5 & \\
\hline 13 & $\mathrm{~F}$ & 70 & 35 & 56.0 & 6.88 & 20 & 72 & \\
\hline 14 & $\mathbf{M}$ & 73 & 35 & 50.0 & 7.04 & 60 & 72 & Ischamic heart disease \\
\hline 15 & $\mathrm{~F}$ & 25 & 5 & 25.0 & 7.07 & 40 & 48 & \\
\hline 16 & $M$ & 19 & 3 & 31.2 & 7.22 & 118 & 30 & $\begin{array}{l}\text { Thyrotoxicosis } \\
\text { Down's syndrome }\end{array}$ \\
\hline 17 & $\mathrm{~F}$ & 38 & 18 & 63.9 & 7.26 & 20 & 84 & \\
\hline 18 & $\mathrm{~F}$ & 23 & New & 36.0 & 7.19 & - & 27 & \\
\hline 19 & $\mathrm{~F}$ & 81 & 37 & 27.6 & 7.32 & 52 & 48 & \\
\hline 20 & $\mathbf{M}$ & 37 & 14 & 74.5 & 7.08 & 40 & 46 & \\
\hline 21 & $F$ & 84 & $1 \mathrm{~m}$ & 62.7 & 7.30 & - & 27 & \\
\hline Mean & & 47 & 16 & 46.3 & 7.14 & 41 & 58 & \\
\hline
\end{tabular}

clinically indicated, using saline $(0.154 \mathrm{~mol} / \mathrm{l})$ and subsequently dextrose $(5 \mathrm{~g} / 100 \mathrm{ml})$ solutions. In control patients, Group 1 (Table 1), potassium replacement was given as the chloride. The phosphate supplemented patients, Group 2 (Table 2), were given IV molar potassium hydrogen phosphate $\left(\mathrm{K}_{2} \mathrm{HPO}_{4}\right)$ in doses sufficient to replace potassium. The mean dose of phosphate was 118 mmol (range $83-320 \mathrm{mmol}$ ) over 2 days. The dose of IV phosphate was adjusted so as to restore and maintain normal plasma phosphate concentrations (normal range $0.8-1.45 \mathrm{mmol} / \mathrm{l}$ ). When patients in Group 2 were able to eat, IV phosphate was replaced by 4-8 phosphate-Sandoz tablets (each containing $12 \mathrm{mmol}$ phosphate) daily for 10 days and were transferred to a three times per day sliding scale of insulin based on blood glucose levels. After $24-48 \mathrm{~h}$ a twice daily regime of Actrapid and Monotard M. C. insulin was instituted. None of the patients was given sodium bicarbonate.

Arterial blood samples were drawn anaerobically and assayed within 20 minutes for $\mathrm{pH}$, oxygen tension and standard bicarbonate. Blood glucose was measured on a Beckman glucose analyser. Plasma calcium, phosphate [10] and albumin were measured by autoanalyser techniques. Red-cell 2,3-DPG was determined on blood deproteinized at the bedside, according to Sigma Technical Bulletin No. 35-UV (Sigma Labs., U. S.), which depends on the decrease in NADH concentrations measured at $340 \mathrm{~nm}$, after the enzymic conversion of 2,3-DPG to $1,3-\mathrm{DPG}$ and subsequent reduction.

The blood oxygen tension at $50 \%$ haemoglobin-oxygen saturation (p 50) was derived from the simultaneously measured haemoglobin-oxygen saturation and oxygen tension in fresh whole blood at saturations of $40-50 \%, 50 \%$ and $50-60 \%$ using the "IL 217 blood gas laboratory" (Instrumentation Laboratory, U. K.). p 50 standard $\left(\mathrm{pH}=7.4, \mathrm{pCO}_{2}=40 \mathrm{~mm} \mathrm{Hg}\right.$ ) and $\mathrm{p} 50$ in vivo (actual venous $\mathrm{pH}$ and base excess) were calculated from this, using the following expressions:

$\log$ p 50 standard $=\log$ p 50 (measured) $-0.40(7.4-\mathrm{pH}$ of assay)

$\log \mathrm{p} 50$ in vivo $=\log \mathrm{p} 50$ (measured) +0.59 (assay $\mathrm{pH}-$ in vivo $\mathrm{pH})+0.003 \Delta$ base excess

These expressions were derived from observations on normal subjects and are similar to those quoted elsewhere [11].

Since the differences between assay and in vivo $\mathrm{pH}$ values were slight (average difference 0.04 units), the correction factors from assay p 50 to p 50 in vivo were small. Alterations in the Bohr factor due to variations in 2,3-DPG concentrations [12] introduce only minimal variation in the predicted $\mathrm{p} 50$ in vivo. We have therefore used a single $\mathrm{pH}$ and base excess correction factor rather 
than factors determined from each individual blood sample. The maximum expected error in the estimated 'Available Oxygen' (see below) would therefore be about $4 \%$

'Available Oxygen', derived from the haemoglobin concentration and $\mathrm{p} 50$ in vivo, is the amount of oxygen calculated to be capable of release per $100 \mathrm{ml} / \mathrm{blood}$ [13].

Measurements of $p 50$ were done over a narrow range of oxygen tensions and determinations of the Hill coefficient (n) would therefore be unreliable. However, our best estimates of $\mathbf{n}$ showed a general increase from about 2.2 to 2.9 during the course of treatment in both groups of patients. The maximum error encountered in the calculation of 'Available Oxygen' as a result of ignoring changes in $\mathrm{n}$ values would therefore occur at the beginning of treatment and would amount to about $8 \%$.

Student's ' $t$ ' test was used for statistical analyses.

Clinical details are given in Tables 1 and 2. Ethical approval for the study was granted by the Hospital Ethical Committee.

\section{Results (Table 3)}

\section{Phosphate}

Initially there was no significant difference between the plasma phosphate levels of the two groups. Patients in Group 1 showed the expected fall in plasma phosphate, below normal, reaching the lowest level (mean $0.64 \mathrm{mmol} / \mathrm{l}$ ) between 24 and $48 \mathrm{~h}$. In patients in Group 2, plasma phosphate was maintained within the normal range. The two groups showed significant differences in plasma phosphate from $12 \mathrm{~h}$ to 8 days after starting treatment. The reduction in urine phosphate in the control patient with insulin treatment is typical; however, Group 2 patients showed very high phosphate excretion throughout the study (Fig. 1).

\section{Calcium}

Plasma calcium concentrations in Group 2 were not significantly different from those found in Group 1.

\section{Red-Cell 2,3-DPG}

The initial 2,3-DPG concentrations of the two groups were not significantly different. The lowest levels were found in the most acidotic patients. 2,3-DPG concentrations rose more rapidly after 24 hours' treatment in Group 2, the difference from Group 1 reaching statistical significance at $48 \mathrm{~h}(\mathrm{p}<0.01)$ and 4 days $(p<0.02)$.

\section{Arterial and Venous pH}

The mean arterial $\mathrm{pH}$ of both groups rose steadily during the first $24 \mathrm{~h}$. There was no significant difference between the two groups at any stage.

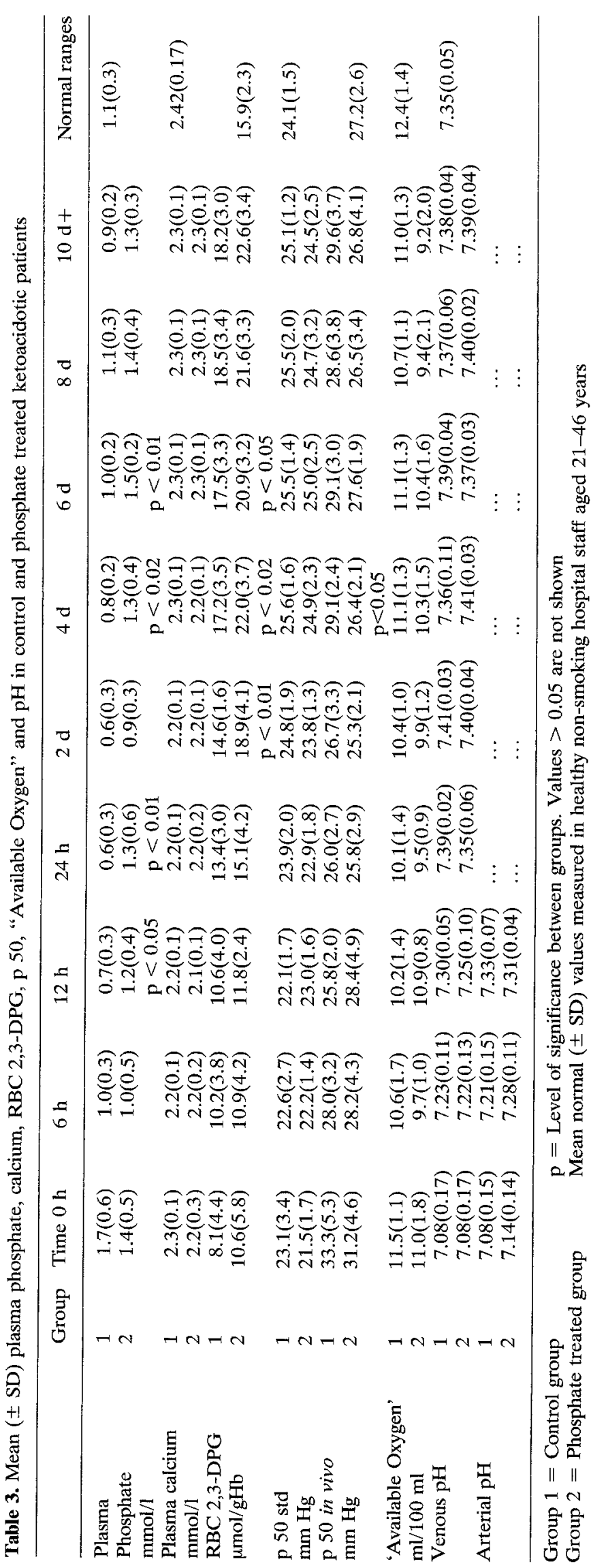




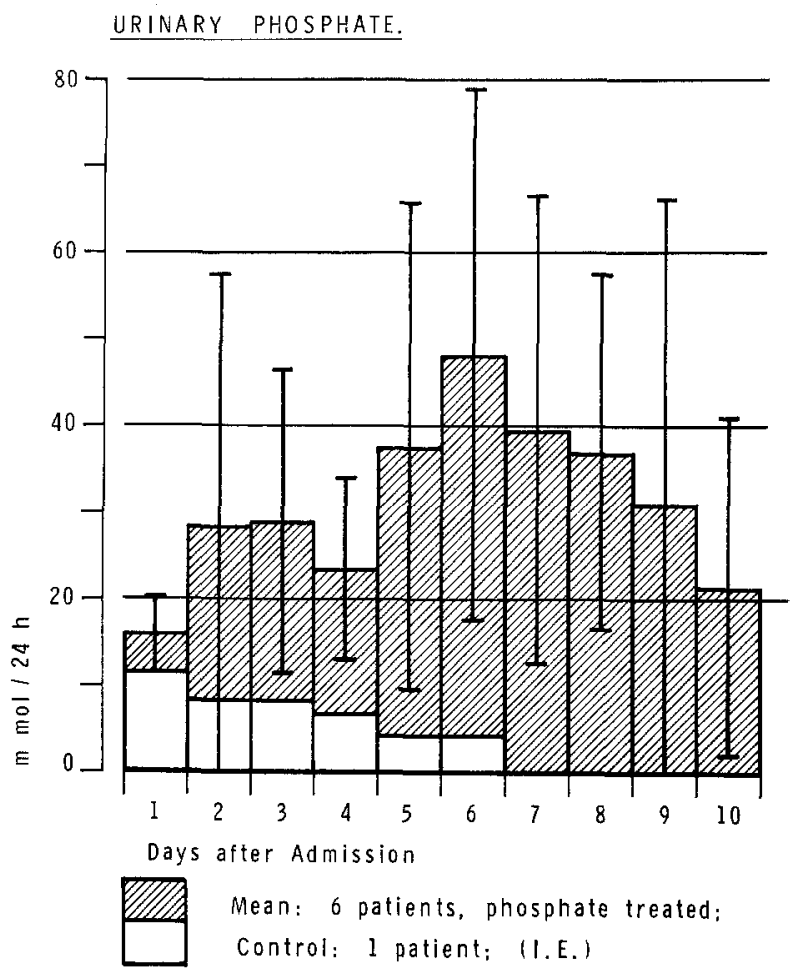

Fig. 1. Urine phosphate excretion in 6 phosphate treated ketoacidotic patients. Mean \pm SEM

\section{p 50 Standard}

There were no significant differences between the values of $\mathrm{p} 50$ standard at any time.

In both groups there was a good correlation between the p 50 standard and the concentrations of 2,3-DPG $(\mathrm{p}<0.001)$.

The regression equations are as follows:

Group $1:$ p $50=19.2+0.35(\mathrm{DPG})$

Group $2:$ p $50=19.5+0.24(\mathrm{DPG})$

Normal : p $50=17.6+0.69$ (DPG) [14].

\section{p 50 in vivo}

Initial values of $\mathrm{p} 50$ in vivo were high but values in the two groups were not significantly different. In both groups lowest levels were reached between $12 \mathrm{~h}$ and 2 days. At 4 days only, p 50 values were lower in Group $2(\mathrm{p}<0.05)$.

\section{'Available Oxygen'}

This calculation includes both oxygen content and $\mathrm{p}$ 50 in vivo. There was no significant difference between the two groups on admission or subsequently. Values fell at $24 \mathrm{~h}$. Haemoglobin concentrations on admission were high due to dehydration. 'Available Oxygen' was therefore calculated using the patients' stable haemoglobin concentrations measured after correction of fluid balance. The 'Available Oxygen' calculated on this basis corrects for the effect of variable dehydration.

\section{Discussion}

This study has demonstrated in diabetic ketoacidosis that phosphate infusion adequate to prevent hypophosphataemia increases the rate of recovery of red-cell 2,3-DPG but only after the first twenty-four hours. However, no significant improvement in haemoglobin-oxygen affinity results at any time. The concentration of haemoglobin $\mathrm{A} 1_{c}$, which was not measured in our study, is increased in poorly controlled diabetics [15]. The high affinity for oxygen of haemoglobin $A 1_{c}$ is little affected by 2,3-DPG [16]. In phosphate treated patients this may have contributed to the failure of the $\mathrm{p} 50$ to rise in parallel with their more rapid recovery of erythrocyte $2,3-\mathrm{DPG}$ concentrations.

We find that $p 50$ in diabetic patients is less sensitive to changes in concentrations of 2,3-DPG than in normal subjects. This contrasts with the findings of Ditzel and Standl in their study of non-acidotic juvenile diabetics [17]. However, both findings are based on the results of population surveys where factors other than the concentration of 2,3-DPG e.g. $\mathrm{pH}, \mathrm{pCO}_{2}$ and phosphate, are varying, and individually influencing p 50 in their separate ways. Ditzel and Standl's findings in their juvenile non-acidotic diabetic subjects cannot necessarily be extrapolated to patients with diabetic ketoacidosis.

The patients in our study varied considerably in age, duration of diabetes and presumably also in pulmonary, cardiac and renal function. As groups however, they were similar (Tables 1 and 2). There was no clinical difference in their response to treatment. Only modest reductions in calculated oxygen availability were found in our patients. At the time of maximal reduction in oxygen availability from the blood, these patients have improved considerably in their clinical state due to the correction of hyperglycaemia, acidosis and dehydration. No practical measurement of tissue oxygenation is available so that direct detection of the effects of changes in 'Available Oxygen' is not possible.

The role of bicarbonate therapy in diabetic ketoacidosis is controversial. Theoretically, it might reduce oxygen availability by rapid correction of acidosis. This induces an immediate 'left shift' of the oxygen dissociation curve before the restoration of red-cell 2,3-DPG. In this study 6 patients with an arterial $\mathrm{pH}$ of less than 7.0 on admission were treated successfully without bicarbonate. 
We have demonstrated that phosphate can be administered safely provided the dose is carefully judged. Impairment of renal function, however, would be a contra-indication to phosphate treatment. Phosphate administration, by mouth or intravenously, causes metastatic soft tissue calcification and renal impairment in patients with hypercalcaemia $[18,19]$. Patients presenting with diabetic ketoacidosis are dehydrated and have raised blood urea concentrations and it is difficult to exclude underlying or impending renal failure. Great care is essential in the administration of phosphate, and we did not see any deterioration in renal function in our patients over the study period. Phosphate administration causes hypocalcaemia. A rapid plasma phosphate estimation would be a valuable safeguard in its use.

Unless it can be demonstrated that actual tissue oxygenation is improved by phosphate treatment in diabetic ketoacidosis, the case for phosphate remains unproven and we conclude that phosphate administration, at least in the doses used in the present study, is not indicated to improve tissue oxygenation in diabetic ketoacidosis.

Acknowledgements. We gratefully acknowledge the assistance of the medical and nursing staff of wards $\mathrm{C}_{2}$ and $\mathrm{C} 7$ and of the medical and technical staff of the Medical Biochemistry Department, University Hospital of Wales. We also thank Mrs J. Brown and Mrs C. Mitchell who typed the manuscript.

\section{References}

1. Alberti, K. G. M. M.: Diabetic ketoacidosis - aspects of management. In: Tenth Symposium on Advanced Medicine. Ledingham, J. G. G. (Ed.), p. 68-82. London: Pitman Medical 1974

2. Guest, G. M., Rapoport, S.: Role of acid-soluble phosphorous compounds in red blood cells in experimental rickets, renal insufficiency, pyloric obstruction, gastroenteritis, ammonium chloride acidosis and diabetic acidosis. Am. J. Dis. Child. 58, 1072-1089 (1934)

3. Ditzel, J.: Raised C. S. F. pressure during treatment of diabetic ketoacidosis (letter). Lancet 1971 II, 925-926

4. Alberti, K. G. M. M., Darley, J.H., Emerson, P. M., Hockaday, T. D. R.: 2,3-Diphosphoglycerate and tissue oxygenation in uncontrolled diabetes mellitus. Lancet 1972 II, 391-395

5. Chanutin, A., Curnish, R. R.: Effect of organic and inorganic phosphates on oxygen equilibrium of human erythrocytes. Arch. Biochem. Biophys. 121, 96-102 (1967)

6. Benesch, R., Benesch, R. E.: The effect of organic phosphate from human erythrocytes on the allosteric properties of haemoglobin. Biochem. Biophys. Res. Commun. 26, 162-167 (1967)

7. Ditzel, J.: Importance of plasma inorganic phosphate on tissue oxygenation during recovery from diabetic ketoacidosis. Horm. Metab. Res. 5, 471-472 (1973)

8. Franks, M., Berris, R. F., Kaplan, N. O., Myers, B.: Metabolic studies in diabetic acidosis. II The effect of the administration of sodium phosphate. Arch. Intern. Med. 81, 42-55 (1948)

9. Kanter, T., Gerson, J. R., Bessman, A. N.: 2,3-Diphosphoglycerate, nucleotide phosphate and organic and inorganic phosphate levels during the early phases of diabetic ketoacidosis. Diabetes 26, 429-433 (1977)

10. Technicon Instrumentation Corporation: Method No. SF40004FF5. Technicon Autoanalyser Bulletin 1975

11. Lichtman, M. A., Murphy, M.S., Whitbeck, A. A., Kearney, E. A.: Oxygen binding to haemoglobin in subjects with hypoproliferative anaemia, with and without chronic renal disease: role of pH. Br. J. Haematol. 27, 439-452 (1974)

12. Arturson, G., Garby, L., Robert, M., Zaar, B.: The oxygen dissocation curve of normal human blood with special reference to the influence of physiological effector ligands. Scand. J. Clin. Lab. Invest. 34, 9-13 (1974)

13. Jones, J. G., Holland, B.M., Veale, K.E. A., Wardrop, C. A. J.: 'Available Oxygen'. A realistic expression of the ability of the blood to supply oxygen to tissues. Br. J. Haematol. (In press)

14. Bellingham, A.J., Detter, J.C., Lenfant, C.: Regulatory mechanisms of hemoglobin oxygen affinity in acidosis and alkalosis. J. Clin. Invest. 50, 700-706 (1971)

15. Gabbay, K. H.: Glycosylated hemoglobin and diabetic control (editorial). N. Engl. J. Med. 295, 443-444 (1976)

16. Bunn, H. F., Briehl, R. W.: The interaction of 2,3-diphosphoglycerate with various human hemoglobins. J. Clin. Invest. 49, 1088-1095 (1970)

17. Ditzel, J., Standl, E.: The problem of tissue oxygenation in diabetes mellitus. II. Evidence of disordered oxygen release from the erythrocytes of diabetics in various conditions of metabolic control. Acta Med. Scand. [Suppl.] 578, 59-68 (1975)

18. Carey, R. W., Schmitt, G. W., Kopald, M. M.: Massive extraskeletal calcification during phosphate treatment of hypercalcaemia. Arch. Intern. Med. 122, 150-155 (1968)

19. Ayala, G., Chestow, B.S., Shah, J.M., Williams, G. A., Kukreja, S. C.: Acute hyperphosphataemia and acute renal insufficiency induced by oral phosphate therapy. Ann. Intern. Med. 83, 520-521 (1975)

Received: March 13, 1978,

and in revised form: Iuly 21, 1978

Dr. T. M. Hayes

Consultant Physician

University Hospital of Wales

Heath Park

Cardiff, CF4 4XW

Wales 